\title{
Sycophancy and Objective Journalism
}

\author{
Bonachristus Umeogu ${ }^{1}$, Ifeoma Ojiakor ${ }^{2}$ \\ ${ }^{1}$ Department of Philosophy, Faculty of Arts, Nnamdi Azikiwe University, Awka, Nigeria \\ ${ }^{2}$ Department of Mass Communication, Faculty of Social Sciences, Nnamdi Azikiwe University, Awka, Nigeria \\ Email: ojiakor99@yahoo.com
}

Received April 28 ${ }^{\text {th }}$, 2012; revised June $2^{\text {nd }}, 2012$; accepted June $12^{\text {th }}, 2012$

\begin{abstract}
Objective journalism is the desire and aim of every society and media house. However, such noble aspiration is beclouded and usurped by sycophancy and sycophantic reporting. This development denies the public the right to true information and invariably leads to loss of reputation by the media house. This paper looks at sycophancy in the Nigerian media by looking at the reasons for its unbridled spread, effects on the public, media houses, individuals and the government of the day.
\end{abstract}

Keywords: Sycophancy; Ethics; Objectivity; Objective Journalism

\section{Introduction}

Despite the time and attention given to ethical issues, our society is still riddled with different types and manner of ethical maladies. The journalist who is a product of the society is willingly or unwillingly affected by the sorry situation. One of such problems is sycophancy which is chief among the ethical problems in Nigeria. The issue of sycophancy is important to be addressed because it affects objective journalism as it is.

Barry white, a renowned singer has one of his lyrics as "practice what you preach". This goes a long way to resound that talk is cheap. It is one thing to know the right thing and a different ball game to do the right thing. These days, everybody knows the slogan of a free but responsible press. Good a thing that everyone knows that; but is it really practiced? Is objective reporting attainable in this era besieged by sycophantic reporting?

Every member of a democratic society has the right to know; since nobody wants to be fed with trash, the summum bonum becomes objective reporting or journalism. Overtime, the press has been riddled with all forms of ethical issues which have invariably affected what goes down to the public as news or information. Such issues include plagiarism, brown envelopism, moon lighting, and of course sycophancy. One thing that is logical is that unethical reporting results to subjective journalism.

The question now is why is Nigerian journalism bedeviled with sycophantic reporting? What are the causes and inherent dangers of this ethical problem? Does it have any ethical implication for the journalist, the government and the society at large? What can be done to remedy the situation to avoid repeating the same old story?

\section{Definition of Ethics}

What is ethics? For a word that occupies such a central place in communication, there abound definitions as there abound communication scholars. That notwithstanding, Omole (2000) in Okunna (2003: p. 2) defines ethics as

the shared normative values, which any society holds dear and are used to judge the behaviour or performance of any member of that society. It sets out the minimum of acceptable behaviour which any member should attain to be regarded as a good ambassador...

Ethics is a concept that borders on morality and consequences of human actions. It also recognizes the fact that man as a rational being has the ability to discern what is good or bad and in line with the approved standard of behaviour in a given society. Thiroux 1980 in (Okunna 2003) concurs by explaining that:

when we speak of people as moral or ethical, we usually mean that they are good people and when we speak of them as immoral or unethical, we mean that they are bad people. When we refer to certain human actions as moral, ethical, immoral or unethical, we mean they are right or wrong.

Another important characteristic of ethics is that it is voluntary in nature. That is, an individual chooses to do right or wrong. Despite associations and bodies that regulates the activities of its members; the decision to be ethical or not depends solely on the individual. That is the relativity of ethical principles. According to Ozumba (2001: p. 2),

ethics as a science of good conduct can hardly on its own make good men out of bad men. Its job is to instruct us on how to be good men if we wish to be. This means that the decision is all ours.

However, that decision to be or not to be might collectively or individually be influenced by variables like sex, level of exposure, orientation, religious background and what have you. Contextualizing them, Okunna (2003) lists them "as cultural socialization, personality differences and situational contingencies".

From the vast definitions of ethics, it can be summarily deduced that ethics is a set of moral principles or values dealing with what is good or bad. It has also been seen as that branch of knowledge that is concerned with the standards of good or bad conduct in society. Journalistic ethics, according to Okunna 2003, is that branch of philosophy which aids journalists in determining what is right to do and is ultimately concerned 
with providing moral principles or norms for journalistic actions. Oloruntola (2007: p. 58) also shares his opinions;

Every profession of repute has for its practitioner's codes of ethics that guide the conduct of members in the performance of their duties. Journalism as a profession is not an exception as such codes of journalistic ethics have been established all over the world both by members of the profession and media organizations.

It holistically recognizes man as a rational being and attempts to maximize the positive inner potential of man for the greater good. Rationality has to do with the ability to make decisions and judgments based on reason. I think that is one of the things that make man a higher animal.

\section{Ethics and the Journalist}

The journalist just like every human being needs an ethical guideline to gauge its activities. The journalist who is like the information house; the eyes and ears of the whole citizenry, particularly needs to be ethically active so as not to misinform or disinform the public.

From time immemorial, man has been under one form of rule or the other. However, journalistic ethics came into the scene following the excesses of journalists during the libertarian era. Ethics as an offshoot of social responsibility theory maintains that in media work, certain standards of performance should not just be stated but followed. This led to the emergence of journalistic codes of ethics for a more responsible conduct. Moemeka 1991 in (Okunna 2003: p. 38) captures this by writing that "this theory places due emphasis on the moral and social responsibilities to persons who, and institutions which operate the mass media".

In the same vein, Merril \& Lowenstein (1979) in (Okunna 2003, p. 48) summarized the importance of ethics in the practice of journalism thus:

ethics - at least a concern for ethics-instills in the journalist a continuing sensitivity to his every action, to his every decision; It integrates or blends with his total search for truth, and it gives him greater awareness of himself, of others, of the consequences of interpersonal relations. A concern with ethics is the key plank in any journalistic platform; it is the "alpha and omega" of public communication.

\section{Purpose of Ethics}

The aim of ethics in journalism is to maintain quality in the media. Ethics is fundamental to journalism because mass media practice is based on a set of essentially ethical concepts of truth, objectivity, honesty, privacy etc. The role of journalism is to provide information for the enlightenment, education and entertainment of the people and this raises ethical question on the quality of the intelligence disseminated, manner of its acquisition and the objective for which it is used in the socio-economic and political processes.

According to Ebeze (2004) journalists have actually derailed from the objective work they are meant to do hence ethnic reporting, wrong information, sycophantic journalism, fallacies reporting; thus, this contributed to the invention of ethics.

In a nutshell, the purpose of ethics for the journalists is
- To protect the consumer, reader, listener or public in general.

In fact, it also helps to protect the journalists themselves before they get drowned in the sea of societal immorality.

- Provides the journalist with standards and principles that will guide the journalist in making moral decisions.

Depending on the different ethical theories and individual differences, ethics will ensure uniform standards of behaviour. This is necessary as some will believe in the rightness of their actions despite the resulting consequence(s); while other will believe that the consequence of the action determines its rightness or wrongness. That being the case, ethics spells out what is expected in a particular situation.

- Provides a duty for yourself and others.

There are individual who play by the books as a matter of principle; ethical provisions or codes of conduct as the case may be helps them to play ball and effectively at that.

- Encourages responsible action in mass communication.

This is the thrust of this paper as ethics has a sole purpose; to encourage free and responsible press so that the consumers have a stable platform to make decisions as rational beings.

\section{For Everybody}

- It enables man to appreciate good or bad.

- Helps individual's live a more virtuous life.

- Promotes and stabilizes social harmony.

- Enables you to look at both sides of the coin before you judge.

\section{Objective Journalism}

What is objectivity and objective journalism? According to Ayodele (1988)

Objectivity is the state or quality of not being influenced by personal bias, prejudice, feelings and opinions. Objective news-reporting is that which is devoid of inferences, judgment and slanting.

Objectivity in journalism is all about stating the obvious devoid of personal emotions and bias. It is more like saying or writing it as it is and not what the journalist will like it to be. In fact, it really takes a disciplined mind to be objective because the temptation to embellish a story is always on the high side. Again, objectivity comes with a great responsibility. Little wonder why Okunna (2003) is of the view that objectivity has a strong affinity with responsibility as far as mass communication is concerned". Corroborating this is Edeani (1993) in Okunna (2003: p. 76) who explain that

objectivity and responsibility are two of the most important concepts in mass communication, in view of the central position occupied by each of them in the performance of the press. Very rarely is press ever criticizes or congratulated on its performance without at least one of these concepts coming into play.

This goes on to show that being objective and responsible is the highest state any press could attain. More like the biblical injunction of "seek to be responsible and objective and every other thing will be added unto you".

Despite the Importance, Gilmore \& Root (1975) in Okunna (2003) describe objectivity as the "short dead-pan news ac- 
count” particularly in the reporting of complex events in which a little interpretation and evaluation are necessary for understanding and assimilation by the publics. This does not deduct from the value of objectivity because interpretative journalism can still be done objectively. This point is buttressed by Edeani (1993) in Okunna (2003: p. 77) when he wrote that

the analysis and interpretation do not detract from, but rather strengthen objectivity if they are done with honesty, fairness and impartiality.

It is agreed that there are cases and stories that requires a kind of interpretation and analysis for better understanding by the consumers. Yet, this does not negate the fact that objectivity is a virtue that should not be compromised in any way. One can still be objective as can be while interpreting. It all boils down to how well you put rein on your emotions. If that is the case, objectivity is not a myth or unattainable but relative to the journalist in question and the principles he/she upholds as ideal.

In other words, Objective journalism acknowledges the public as rational and capable of handling the truth despite how much it hurts. This does not negate the fact that some situation might call for censorship but not at the expense of objectivity.

Writing on the place of objectivity in journalism, Ayodele (1988) opines that

Objectivity in the collating and presenting of news is the goal of the reporter, and a major principle of Journalism. In spite of the fierce competition among newspapers, newsmagazines, radio, television, or wire services, in regard to who gets a story first and is fastest in making such news items public property, objectivity in the disseminating of news is acknowledged as a significant hallmark of modern Journalistic practice.

In the face of intervening variables like pressure, is objectivity really attainable? An answer can be seen in the words of Ayodele (1988) that

...that objectivity in news reporting is a definitely attainable goal, but that one must strive for it even in the face of opposing realities. Adherents of attainable objectivity in the media claim that the reporter need not shy away from his prejudices, pre-conceptions, feelings and ambitions. He need not pretend to be an automaton-unthinking, unfeeling, unemotional; "saying it as it is", with bland facts and figures, and no analyzing nor interpreting. Rather, the journalist is to struggle to place under leash his biases.

It all sums up my earlier premise that objectivity is attainable and relative to the journalist who chooses to be ethical or not in the face of challenges. I also want to reiterate that in journalism, there is no room for ethical flexibilities; either you are ethical or you are not ethical.

\section{Ethical Problems}

The society directly or indirectly influences the people negatively or positively. The journalist who does not exist in a vacuum is also a product of that society. In the course of being professional, the journalist is confronted by demons in the form of ethical problems and they include sycophancy (which is the thrust of this paper), pressure, character assassination, bribery, plagiarism, moonlighting and what have you.

\section{Sycophancy}

Sycophancy is one of the most depressing problems in mass communication. According to Obaze \& Fasahnu (2006: p. 138), sycophancy is a situation whereby a medium continues to praise government or individuals despite ills or incompetence in office. Again, it has been defined by (Okunna, 2003) as false praises of those in power. Locally and internationally, this has been a source of concern to both practicing and budding journalists. The second principle in the international code of ethics has it that

the foremost task of the journalist is to serve the peoples' right to true and authentic information through an honest dedication to objective reality whereby facts are reported conscientiously in their proper context, pointing out their essential connection and without causing distortions, with the deployment of the creative capacity of the journalist so that the public is provided with adequate material to facilitate formation of an accurate and comprehensive picture of the world in which the origin, nature and essence of events, processes and state of affairs are understood as objectively as possible.

Coming back to Nigeria, NUJ knowing the relevance of Accuracy has it as one of its principles and it reads thus:

1) The public has the right to know. Factual, accurate, balanced and fair reporting is the ultimate objective of good journalism and the basis of earning public trust and confidence.

2) A journalist should refrain from publishing inaccurate and misleading information. When such information has been in advertently published, prompt correction should be made.

3) In the course of his duties, a journalist should strive to separate facts from conjecture and comments.

If the above is religiously followed, what the consumer gets will be nothing short of objective and factual reports.

Objective reporting on the other hand is that report that is devoid of inferences, judgments and slanting. It is the absence of objectivity that invariably leads to sycophantic reporting. According to Okunna (1995), "a sycophant reporter is a journalist who flatters political leaders, wealthy citizens and owners of media houses who as employers have formidable power over journalist". For instance Jacque Chirac, a onetime president has been found guilty of two count charges of corruption and misappropriation of public funds. According to a media report on Aljazeera network, he employed ghost workers at the city hall and diverted the money for his campaign. This is the same man who the media while in power never criticized. Despite the political immunity covering government officials, my question is if the press never knew he was siphoning and diverting funds at the time he was in office? From previous happenings, I want to believe that they were aware but choose to be mute about. How do they live with their conscience highlighting praises of someone who has committed a crime but rather chose to sweep it under the carpet or turn a blind eye?

In Nigeria, this is more pronounced in the political sphere where journalists use the media to confer status on their favored politicians and also to set agenda that will also favour the favored ones, Okunna (1995). 


\section{Causes of Sycophancy}

There are many possible causes of sycophancy but this paper will look at the following.

\section{Lack of Experience on the Part of the Political Leaders}

In civilized countries or the developed world, leaders are well versed and more mature and so appreciate constructive criticism as against their counterparts in developing countries where criticism is a no. For instance Barak Obama of the United States of America knows that criticism sharpens one's initiative while Nigerian leaders will see such writer as the worst enemy of the State, and one would not be surprised if the writer is silenced forever.

This being the case considering the immaturity of the leaders and the promise of death, the journalists will praise them despite their ratings so as not to be at loggerheads with them. Look at what happened to Dele Giwa all in a bid to be true to his profession. He was murdered through letter bombing all in a bid to silence his honest voice. Also considering the fact that most journalists in Nigeria and other developing countries are uninsured, they will not like to lose their life in exchange for a colorful and lengthy oration at the funeral ceremony. However, in the developed countries, they will dare the odds even at the expense of their life as their names will be written in the sand of time but in a country like Nigeria, who really cares about the sand of time?

\section{Prevailing Situation or Environmental Contingencies}

The journalist in Nigeria does not operate in a social vacuum. If the society is morally deficient, how is the journalist expected to rise above the moral decay. The journalist according to Olomuyiwa (1988) is a product of the society. According to this writer,

the African society with its various facets-tradition, beliefs, images, goal, constraints etc must inevitably influence and be influenced upon by the journalist. The journalist helps to shape the size and direction of what is communicated to the different publics of the media.

As far as information flow is concerned, they are the major gate keepers in mass communication. They in turn, indirectly sets his/her own agenda; what he/she finally select to communicate. You can see that both the powers of the journalist and the public's are interwoven to an extent.

Explaining this, Olomuyiwa writes that this dual yet interactive role has its implications for the constant barrage of charges of bias, prejudice, partisanship, untruth and especially sycophancy leveled against the media and its staff. That is to say that the level of unethical practices among Nigerian journalists is a reflection of what is happening in the larger society. Lai Oso (2001).

In other words, journalists tend to succumb to the prevailing situation because when the society is immoral, objectivity and truth is thrown to the winds.

\section{Lack of Professional Education or Training of Journalist}

The right formal education is one powerful tool for the mak- ing of ethical profession. When you pass through the rigorous processes of training, then you will learn to appreciate your profession and yourself; and will guard its prestige jealously. In fact, studies have revealed that journalists with higher education exhibit more professional orientation in performing their duties.

Oso (2001) observes that

a good number of those who go about these days as journalists have either not received any education/training in journalism or are not adequately trained and equipped for the challenges of the profession.

What this shows is that the more educated one is, the more confident and secured the journalist will feel to take on the challenges that are bound to surface.

\section{Poverty}

This is the chief cause of ethical misconduct; the mother that gave birth to other problems. An averaged journalist lives below the poverty line; and until the issue of poverty is seriously addressed with realizable solution, then no amount of constitutions or codes of conducts will have any meaningful impact.

Nothing is perhaps more important than a good pay to keep the reporter on the ethical path. According to Garba (1998) "Abiola used to say that when you do not pay your journalist well, someone else will pay them and they will work for him”. This is dangerous because as an employer, you will be unaware that your employee is moonlighting which poses a threat to both employers but a bigger threat to the one that do not give fat salary. This invariably aids moonlighting as an option to dealing with poverty. Worthy of note is the fact that moon lighting is also an ethical problem in Nigeria that has been generating great concern.

Nigerians are known to be survivors and the journalist must also strive to survive even in the face of abject poverty to the extent of cutting corners. However, this depends on individual because the sycophantic tendencies of a journalist are to a great extent determined by the bias, prejudice and constraints personal to him. What I am trying to say is that there are still people who believe that "a good name is better than riches.

\section{Influx of Government Owned Media}

If the saying that "whoever pays the piper dictates the tune" is anything to go by, then we must empathize with journalists that work in the government owned media. They are like birds in a cage that have their wings clipped and their legs chopped. They can only move when their owner wants them to. In other words, they do not have a will of their own; more like automated robots that move only when commanded to. What a life!

One can now understand why they conveniently play the role of praise singers for the government of the day as if it is the "natural" thing to do. In reality, journalists have a duty to be objective at all times. The concept of duty therefore entails the necessity of acting from respect for the law. This implies that we have a moral obligation to do the right, remaining indifferent to the consequences.

Saying or writing things as they are might bring the reporter and the government at loggerheads but Kantian opinions of duty is deontological or obligatory. According to Kant in (Ojiakor, 2004), acting from a sense of duty rather than concern and 
consequences is the basis for establishing one's moral obligation”.

\section{Sycophantic Reporting}

Each passing day brings modifications to the already powerful effects of the mass media. This absolute power calls for a check to ensure that the public's right to true information is not compromised. In other to be fair and truthful, the watchword is objectivity. However, is Nigerian press objective?

To attempt to answer that question, several national dailies in Nigeria were content analyzed to pin point the instances of sycophantic reporting. Comparatively, old and current dailies were compared to see if the trend has remained the same or if there has been a change in the status quo.

Again, garland for the oriental Amazon-this report highlighted and extolled the achievement of Dame Virgy Etiaba or "Mama Anambra" as she was popularly known by the citizens of Anambra State where she served as an executive governor. They recalled that she awarded contracts for 500 kilometers of roads, paid leave allowances of civil servants from 2003-2006, recruited teachers and what have you. No mention was made of the millions of naira siphoned during her short stay as the governor. The impression was that she initiated the contracts conveniently neglecting the part that her predecessor called the shots before a legal battle that saw our "mama" to the highly coveted seat. She may have done all that and more but the story read like a PR insert to praise her while indirectly character assassinate her predecessor. The story would have been balanced if they had brought in her weaknesses even if they downplay them a bit (The Guardian, 2007: p. 61).

Second example was in National Mirror newspaper with the headline as "the man the cap fits" and another story on the same paper that ran as "Sam Egwu: the father of modern Ebonyi State”. It went on to explain how he transformed Ebonyi State into veritable heaven as the then governor of the State. No one gets it all considering that the worst part of management is human management. As a human and rational being, he must have made bad decisions and had his own share of bad moments. I suppose that aspect is on a need to know basis. Was it an objective report?

A look at the Guardian paper of $9^{\text {th }}$ October, 2007 will see this headline "Unizik: the making of a modern university". To be truly objective, effort would have been made to get the views and opinions of the students and staff. Such revelations no matter how bad they may seem at that time will help to know the important areas to address. For instance, what about the transportation problems of students, the frustration of students by unethical lecturers, and the politics of admission process which by the way is common among tertiary institutions? A balanced report will have signaled more significant development processes.

In the electronic media especially the State owned stations, that is the order of the day. Even when a government has become unpopular, their mouth piece in the name of the press still sings their praises. One can now understand why some citizens prefer to watch and listen to "serious" networks like Aljazeera for objective news. Objective news according to Ayodele (1988) is news that is undistorted by personal prejudice. It is news that is fair, accurate, and factual. Nevertheless, it is not news that has been gathered and presented by an unthinking, unfeeling professional. Objective news is devoid of inference, judgment, and Slanting”.

Comparatively, let us examine some current dailies before arriving at a conclusion. Purposively, this researcher chose to choose dailies from $1^{\text {st }}$ November 2011 to $30^{\text {th }}$ December, 2011. This was to content analyze with a view to fishing out sycophantic reports. The dailies are the Guardian, This Day, The Sun and The Vanguard Newspapers.

I want to draw your attention to Daily Sun of December 29, 2011 with the headlines as "Obi's strides in Anambra State. The writing was on the efforts and impacts of ANIDS on the development of the State. I quote "it is fairly reasonable to argue that Governor Peter Obi of Anambra State is a handworker. This fact is not constable, at least to keep observers of development progression in the State within the last five years".

He went on to list the remarkable improvements made in the education, health, judiciary, transportation, environment, industrialization, security, roads etc. I want to make it clear that the researcher does not agree with the writer but to an extent, I beg to differ. Let us look at education sector for an instance; reformation in the education sector is at whose expense? How much do State owned universities pay as tuition fees? In the secondary school section, there is inadequate teachers which led to a situation where teachers are employed by the school management with the consent of the Parents Teachers' Association who pay the salaries of those teachers PTA levies, and not the government. If the school excels in academics, the government takes the credit. I do not want to believe that the writer did not conduct a research before this write up, if he did, then he would have found a way to applaud the concerned parents who are pulling their weight to reform the education sector for the betterment of their children and the society at large.

Coming to the transport sector, I want to ask; does the state of roads affect the transportation fares? My answer is yes! Way before the price hike as a result of the removal of fuel subsidy, passengers have been paying more than usual owing to bad roads especially the Onitsha-Awka expressway. No, I do not want to go into whether it is a federal or State road because it does not change the fact that it is a death trap. Surprisingly, this reporter wrote in from Onitsha yet conveniently left out the state of the roads when he was commenting on the transport sector. If this is not a sycophantic report, then why not call the attention of the object of your praise to what the masses are going through as a result of the roads. Some of the aftermath of the roads on the masses are; lateness to work since they have to avoid the potholes and the bumps, ill health because bumpy rides always have their toll on the body, holes in their pockets since they spend supposed savings on transportation etc. At this juncture, I want to refer you to a report on National mirror of December, 12 where the State Assembly decried the deplorable state of Nneogidi-Agulu Nise road, passing a motion on the State governor to give out the contract for the road construction. I can go and on to fault this report, but let us look at other dailies.

There was also a report on Guardian of November 15, 2001 with the headline as "Chime reassures Enugu youths of employment opportunities. It was a report of the Governor of Enugu State, Mr Sullivan Iheanacho Chime, reassuring the people in Lagos that he is on the verge of creating employment opportunities in the State. It also mentioned his efforts towards that by registering job seekers, collaboration with National Directorate of Employment (NDE) and what have you. I am curious to know how he intends to achieve all this when it is 
difficult for him to pay the minimum wage to his workers. If you cannot pay the workers you already have, with what are you going to pay the new recruits? Well, unless the job opportunities will be for the artisans; if that is the case, what happens to the graduates? Are they over qualified to be meaningfully engaged by the government at all levels?

What we were not told was if it was a press conference or a social function because a smart journalist or a courageous member of the audience would have asked this question. This writer should have questioned this development.

However, it was observed that the two months selected had something in common; they were filled with stories about and on the death of the CEO of guardian newspaper, Alex Uruemu Ibru and Chief Odumegwu Ojukwu; the National Awards by the Presidency on the selected few; and the pros and cons of the removal of fuel subsidy. Almost half of the selected newspapers were filled with stories of the above mentioned issues and/or congratulatory message to the award recipients and even birthday messages to the Nigerian president, Dr. Goodluck Ebele Jonathan. As a result of this observation, it calls for an in-depth content analysis of the publications prior to the November/ December issues.

\section{Dangers of Sycophantic Reporting} low:

The inherent dangers of sycophancy have been outlined be-

- It makes the entire profession to lose its credibility or to be irritating to the public who often see through the masks. This could be the reason why Aljazeera network is preferred when it comes to objective news. This shows that the audiences are active and knows which station carries correct news and those that air doctored news. Explaining that the publics are no fools, Ajayi-Gbadabo (2000) writes that "protecting citizens against unfair media reports is the responsibility of the press to ensure that citizens are protected from media excesses that can amount to assault on the sensibilities of the people".

- It is now virtually impossible for the journalist to effectively discharge his duty while he is so much involved in over-praising.

- It is difficult for those being praised to perform impressively. This is because the praises will becloud their vision. According to Okunna (2003), sycophancy leads to dereliction of duty because they are not allowed to see the mistakes and correct them. Even when they realize that they are not doing well, they are content to hide behind the misinformation by the press under the illusion that the public will be none the wiser.

- It leads to abuse of power of the mass media. According to (Okunna, 2003: p. 87), during elections, unethical journalists use the media to confer status on their favorite politician and to set the political agenda in favour of these politicians even when they lack legitimacy and do not deserve the praise heaped upon them”. The electorate who is powerless in the face of the all powerful effect of the media is deliberately manipulated into adopting that candidate. In Okunnas' opinion, this manipulation is one of the negative effects of sycophancy. On a second thought, does sycophancy have any positive effect?

- It denotes the public their right to true and correct information. Using the report on Obi as an example, if I have been none the wiser, could you imagine the noise I will making in the course of arguing that the governor have performed above expectations. To people that knew the true state of things, I will sound like an empty drum. That is why the public needs to be given true and correct information so that they can make their judgments.

- It has no redress in court. Unlike libel and slander for which one can sue a publication, there is no constitutional provision for sycophancy. If there is, journalists would have been careful not to be dragged into a legal battle.

- False praises bring about false behaviour.

To make it clearer, let us divide it into ethical implication for the journalist, government and the society.

\section{On the Journalist}

The implication of sycophancy on the journalist is that it does not allow the journalist to criticize the government. But then, what do you expect since who pays the piper dictates the tune and dance steps as the case may be. Furthermore, the journalist who is no longer objective irritates the media audiences who often see through the falseness of the media content packages by the unethical praise singer, Okunna (1995). This ultimately leads to loss of credibility and respect for the media. The situation is clearly put in the biblical proverb that "of what use is salt if it loses its taste except to be thrown outside and trampled upon”.

In addition, since the journalist is so much involved in over praising, when will he/she have the time to report other things that are happening around him to the detriment of the public. On listening to State owned media, the news package is always what the State governor did or is planning to do. What about those events that are happening in the State that the public need to know about? When the lens of the press is one the government officials and newsmakers, who watches the State?

\section{On the Government}

As noted earlier, false praises bring about false behaviour. This means that if you are not doing it right and the media is saying that you do, you will now relax and overlook your duties. In the words of Okunna (1995), it leads to dereliction of duty on the part of the recipient of the false praises.

This over praising acts as a curtain where they hide behind the flattering, but thankfully, the people are no fools. Whenever a government comes to power, there are expectations on the part on the electorates; so when the road are in bad condition and the press is telling them that the government is building roads, are they trying to play on their intelligence. After all, "you can tell a blind man that there is no oil in the soup and not pepper", in this case, we have eyes to know when a government is making good of his promises.

\section{On the Public}

The public has a right to know and to true information but sycophantic reporting denies them this right. It is a known fact that the result of sycophancy is mis information/dis information as facts are distorted and information is doctored to please an egocentric sponsor. Furthermore,

as the game of praise singing goes on, the journalist fails to do the job that needs to be done which is catering for the diverse informational and communication needs of the public in a conscientious and responsible manner-a 
failure which is a betrayal of the trust which the public places on the press to champion public interest (Edeani in Okunna 1995).

\section{Recommendations}

Decades after Nigerian renowned musician cum evangelist Sunny Okosun asked which way Nigeria in one of his songs, no definite answer has been given rather, our society is still heading downwards socially, economically, morally etc. That notwithstanding, all hope is not lost if only there will be reorientation in our beloved country. There are things that were a taboo in the past that have come to be recognized as a "natural" or "normal" thing in our society. For instance, advance free fraud or 419 as popularly known in Nigeria have come to be seen as the profession of smart and intelligent people. I remember growing up that when men that made money comes back home, people are generally reluctant to accept any form of gifts from them. That has changed because such people are now besieged by their community to accept titles. Yes! That is how far we have morally derailed. If there should be a kind of mind management package to alter the current picture in our heads that the end justifies the means, maybe, the society in general and the journalist in particular will wake up to the clarion call of objective journalism.

In addition, if the press should say, when a government is still power, what they say when they have left power; we may be nipping sycophancy in the bud. For instance, when Ngige was in power, everyone including the State owned media knew he has a stolen mandate but kept quiet about it. The moment he stepped down, the media became over flogged with negative stories about him.

Another instance is that of Jacque Chirac who has been convicted on two counts charges of corruption and embezzling of public funds. The press knew this was happening and kept mute. Had it been they subtly hinted that Chirac has been busted, the level of the embezzlement would not have been so high as to earn a conviction. There is a way of stating the obvious without being hurtful. It all goes down to choice of words and presentation which the journalist is expected to be familiar with.

In addition, I also recommend that the issue of sycophancy having no legal implication should be urgently addressed so as to cut down its presence in Nigerian journalism. In as much as it is fair to acknowledge when someone does a noble thing or delivers on his manifesto; it should be a serious crime to overdo it. Constitutionally, there should be a boundary when praising; and when it is false praise singing, it leads to distortion of facts with the intention to deceive and that, should be a serious crime if the fight against corruption is expected to hold sway.

On a lighter note, this paper recommends that government and corporate bodies should create platforms to honor the journalist who have been true to their profession. When one knows that all actions are on the radar, they will be forced to dance in line; with time, it will feel like the "natural" way to act and everyone becomes a winner.

Finally, I will like to add better remuneration and condition of service of journalists. I will like to point out that this will work in conjunction with a reorientation. This is because according to Ebeze (2007), how much is really enough? What this means is that it is not about money but about re orientation. This is because if you are paid millions of naira, that tendency to cut corners will still be there. Furthermore, how much is really enough considering the fact that "more money attracts more problems"?

Also writing on remuneration, Mohammed 1996 in Oloruntola 2007explains that

"while journalist in the west may be well paid, insured, endowed with state of the art equipment and facilities and are highly mobile; their third world, and particularly Nigerian counterparts are poorly paid, uninsured, immobile and with poor working environment”.

No wonder such job insecurity makes them vulnerable and susceptible to corruption and abuse of professional ethics. If poor remuneration makes them to be unprofessional, then it is logical to assume that a better pay packet will alleviate the problem.

\section{Conclusion}

I wish to start my conclusion with the wise saying of $\mathrm{N}$. N. Evarts that "as there is nothing great in the world but man, there is nothing truly great in man but character".

Objectivity in journalism is not an abstract concept or an unattainable feat. Truth be told, it is supposed to be the goal of practicing reporters and budding journalists to strive for objectivity which is contained in the larger ideal of truth. Again, also considering the enormous power vested in the media, the press owe it to the people to rise and live above the sea of corruption that is threatening to drown this country as we know it. As always, they will be solidly backed by the agenda setting and all powerful effects theories of communication effects.

Every journalist in particular and every member of the society should embrace morality and ethics as an unbreakable principle. By so doing, it will ensure that future generations are brought up with a sense of responsibility and impartiality. Again, there should be no room for ethical flexibilities; either you are ethical or not. The ethical ones should be applauded and encouraged so as to sway the unethical one into being morally firm. This is in appreciation of the fact that people change from time to time. It is about time to change for the good.

I understand that re orientation and subsequent erasure of pictures in our heads will not happen overnight; but it has been said that a journey of a thousand miles begins with not only a step with that determined person. Will you be that someone?

\section{REFERENCES}

Adum, A. (2008). New media: The ethical question. In International Journal of Communication (No. 9, pp. 423-432). Enugu: Ebenezer Productions

Daily Sun (2011). Obi’s strides in Anambra. 29 December 2011, 20.

Ebeze, V. (2007). Unpublished lecture notes. Awka: NAU.

Garba, S. (1998). Corruption in the media. Abuja: Nigerian Press Council.

National Mirror (2007). The man the cap fits. 8 November 2007.

National Mirror (2007). Sam Egwu: The father of modern journalism. 8 November 2007.

National Mirror (2011). State assembly calls on the governor. 12 December 2011.

Obaze, A., \& Fashanu, F. (2006). Mass communication law and ethics. Ibadan: Safinos Publishers.

Ojiakor, I. (2004). Ethical journalism: A critique of Immanuel Kant's ethical philosophy. Awka: NAU.

Okunna, S. (2003). Ethics of mass communication. Enugu: New Generation Ventures Ltd. 


\section{B. UMEOGU, I. OJIAKOR}

Olomuyiwa, A. (1988). Objectivity, sycophancy and the media reality in Nigeria. Africa Media Review, 3, 106-120.

Oloruntola, S. (2007). Mass MEDIA ethics in Nigeria: The problem facing the Nigerian journalist. English Studies, 1, 58-68

Oso, L. (2000). Inculcating ethical standards through education and retraining. Ibadan: MFD/IF Seminar.

Ozumba, G. (2001). A course text on ethics. Lagos: Obaroh \& Ogbi- naka Publishers Ltd.

The Guardian (2007). Again, garland for the oriental Amazon. 3 November 2007.

The Guardian (2007). Unizik: The making of a modern university. 27 October 2007.

The Guardian (2011). Chime reassures Enugu youths of employment opportunities. 15 November 2011. 